\title{
Characteristics of Ethanol, Butanol, Iso-Octane and Gasoline Sprays and Combustion from a Multi-Hole Injector in a DISI Engine
}

Copyright @ 2008 SAE International

\begin{abstract}
Recent pressures on vehicle manufacturers to reduce their average fleet levels of $\mathrm{CO}_{2}$ emissions have resulted in an increased drive to improve fuel economy and enable use of fuels developed from renewable sources that can achieve a net reduction in the $\mathrm{CO}_{2}$ output of each vehicle. The most popular choice for spark-ignition engines has been the blending of ethanol with gasoline, where the ethanol is derived either from agricultural or cellulosic sources such as sugar cane, corn or decomposed plant matter. However, other fuels, such as butanol, have also arisen as potential candidates due to their similarities to gasoline, e.g. higher energy density than ethanol. To extract the maximum benefits from these new fuels through optimized engine design and calibration, an understanding of the behaviour of these fuels in modern engines is necessary. In particular, the use of direct injection spark-ignition technology requires spray formation and combustion characteristics to be quantified in order to improve both injector design and operating strategies. To this end an optical investigation of spray development and combustion was undertaken in a single-cylinder direct-injection spark-ignition engine with a centrally mounted multi-hole injector. Specifically, crank-angle resolved imaging studies were performed and batches of images from 100 consecutive cycles were acquired with synchronised in-cylinder pressure logging. The engine was motored and fired at 1500 RPM stoichiometrically under part load $(0.5$ bar intake pressure), with injection timing set early in the intake stroke to promote homogeneous mixture formation. The effects were investigated at engine coolant temperatures of $20^{\circ} \mathrm{C}$ and $90{ }^{\circ} \mathrm{C}$ using gasoline, iso-octane, ethanol and butanol. Projected spray areas as seen through the piston crown were calculated to reveal information about the atomization and evaporation processes for each fuel. Additionally, flame areas and centroids were calculated to analyse the combustion process relative to measured in-cylinder pressure histories.
\end{abstract}

\author{
J. Serras-Pereira and P.G. Aleiferis \\ J. Serras-Pereira and P.G. Aleiferis
University College London, UK \\ D. Richardson and S. Wallace
Powertrain Engineering, Coventry, UK \\ D. Richardson and S. Wallace
Jaguar Advanced Powertrain Engineering, Coventry, UK
}

\section{INTRODUCTION}

The application of alcohol fuels in spark ignition engines is not a modern development. As far back as the early 1900s Henry Ford intended his first model T and most other new road vehicles to run on ethanol from renewable sources. The discovery of numerous oil fields and the higher compatibility of gasoline with engine materials, among other factors, meant that ethanol take up was slow and was eventually replaced by gasoline. Today's increasing awareness of the human contribution to global warming, as result of excess $\mathrm{CO}_{2}$ emissions, and the question marks surrounding the sustainability of an oil-based world economy, have lead to a renewed urgency and increased research efforts to find alternative 'carbon neutral' sources of energy for the transportation sector, which in the UK alone accounted for $\sim 28 \%$ of all $\mathrm{CO}_{2}$ emissions in 2005 [1].

There is significant potential to reduce $\mathrm{CO}_{2}$ emissions using direct-injection spark-ignition engines by adopting new technologies such as turbocharging and variablevalve actuation with downsizing concepts [2, 3]. However, unless operation with alternative renewable fuels is incorporated, it will not be possible to meet future $\mathrm{CO}_{2}$ emissions targets. Moreover, unless these fuels are compatible with existing distribution infrastructure and engine components, voluntary take up by vehicle manufacturers is likely to be slow and dictated only by the requirement to meet new waves of legislation. For these reasons the current study investigates the spray development and combustion characteristics of ethanol and butanol in direct comparison to gasoline and isooctane fuels. The former alcohol is currently the most common and widespread alternative to fossil fuels but still faced with significant obstacles for use in concentrations higher than $10-15 \%$ with gasoline, whilst the latter alcohol is a more compatible alcohol fuel for use with current vehicle and engine technologies, as well as with existing supply and distribution infrastructures. 
In terms of engine performance, the benefits of using ethanol are generally viewed as positive due its higher octane rating - increasing its knocking resistance and allowing the use of higher compression ratios which improves thermal efficiency. This is compounded by significantly higher charge cooling capability compared to gasoline. However, the low energy density of ethanol impacts a vehicle range between re-fuelling periods and therefore is a set-back from the perspective of the consumer. In this respect, the much smaller difference between energy densities of gasoline and butanol, make this an interesting alternative, particularly given its compatibility with current vehicle technologies.

Recent work has concentrated on investigating the potential benefits of ethanol or ethanol/gasoline blends using thermodynamic engines and quantifying the effects in terms of engine performance and particulate, unburned $\mathrm{HC}$ and $\mathrm{NO}_{x}$ emissions [4-6]. However, there is little existing literature on the fundamental differences between spray formation of alcohol-based fuels versus standard gasoline, particularly for direct-injection configurations. Moreover, very few reports are available on optical studies of mixture preparation and combustion processes using alcohols and all but none featuring new generation multi-hole injectors or other alcohols than ethanol, especially butanol. Analysis of spray and atomization phenomena with reference to fluid properties is also rare but it is vital in providing assessment and interpretation of the fundamental behaviour of these fuels inside engines. Optical studies of sprays and combustion also provide an essential database for developers and modelers due to the very limited data available on spray break-up and flame speeds of alcohol fuels [7-10].

This work seeks to examine the effect of fuel type on incylinder spray development and combustion from a DISI multi-hole injector operating under realistic engine conditions of temperatures and load by:

- Characterising the effects of engine temperature on spray development in a motoring engine for four fuel types, namely, chemically pure ethanol, butanol and iso-octane, as well as a standard multi-component commercial gasoline.

- Investigating the behaviour of these different fuels in a firing engine by studying in-cylinder flame growth and motion on a crank-angle resolved basis for different engine temperatures.

- Carrying out analysis of spray and flame parameters relative to in-cylinder pressure parameters to link observed spray effects to flame growth behavior.

In order to study such interactions, a single-cylinder optical DISI engine was used for high-speed imaging of the fuel spray and flame growth through the piston crown, along with acquisition of in-cylinder pressure via a piezoelectric transducer mounting in the cylinder head.

\section{EXPERIMENTAL ARRANGEMENT}

\section{OPTICAL ENGINE}

Engine Geometry: Experiments were carried out with the same 4-stroke single-cylinder DISI engine and set-up as that used in previously reported work [11, 12] where detailed information about engine and ancillary systems, as well as possible optical arrangements can be found. Therefore only a summary of the engine installation will be given in this paper.

The engine has a prototype cylinder head supplied from Jaguar Advanced Powertrain Engineering with a 4-valve arrangement and has similar bore and stroke geometry to that of a production V8 as outlined in Table 1. It should be noted that in this paper $0^{\circ}$ Crank Angle (CA) corresponds typically to intake Top Dead Centre (TDC) and crank-angle timings will be mainly presented with respect to that as ${ }^{\circ} \mathrm{CA}$ After intake TDC (ATDC).

The engine allows for a number of optical access configurations, namely using a piston crown window, a full quartz cylinder liner and a fixed triangular pent-roof window, all of which were used in the current study to set-up lighting or imaging planes so as to study incylinder spray formation and flame growth.

Table 1. Optical Engine Specifications.

\begin{tabular}{|l|l|}
\hline Engine Base Type & Jaguar V8 \\
\hline Cycle & 4 -Stroke \\
\hline Cylinders & 1 \\
\hline Valves & 2 Intake, 2 Exhaust \\
\hline Bore & $89.0 \mathrm{~mm}$ \\
\hline Stroke & $90.3 \mathrm{~mm}$ \\
\hline Compression Ratio & $11.15: 1$ \\
\hline Maximum Speed & 2500 RPM \\
\hline Valve Timings & IVO $24^{\circ}$, IVC $274^{\circ}$, EVO $476^{\circ}$, EVC $6^{\circ}$ \\
\hline
\end{tabular}

Injection System: The fuel injection system comprised a pneumatic pump to produce 150 bar pressure in the fuel line. A $2 \mu \mathrm{m}$ high-pressure filter element was used on the pressure side with a 150 bar check valve in series to guarantee removal of any impurities and reduce pressure pulsations in the fuel line.

The injector used was vertically positioned and centrally mounted in the combustion chamber with a 6-hole nozzle in a close spacing arrangement with the spark plug. The outer nozzle holes are $0.5 \mathrm{~mm}$ in diameter at the exit and essentially consist of two groups of 3 nozzle holes. The spray pattern is illustrated in Figure 1, where plumes 1 and 6 pass around the spark plug. 

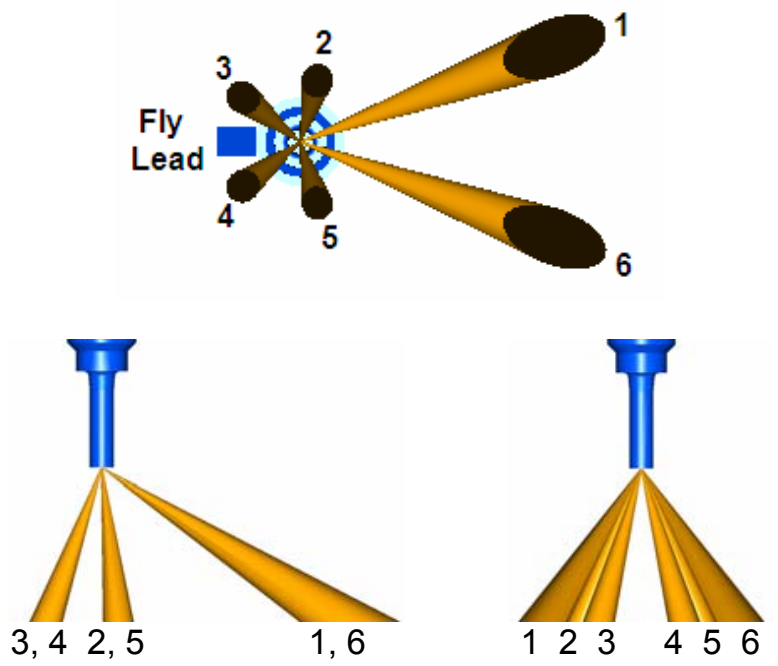

Figure 1. Orientation of the Injector Spray Plumes.

Ignition System: The ignition system used is a single coilon-plug type, using a shared $12 \mathrm{~V}, 25 \mathrm{~A}, \mathrm{DC}$ power supply. A $12 \mathrm{~mm}$ diameter NGK-R spark-plug with a platinum-tip central electrode with J-type ground electrode and cone insulator was used. The dwell or charge time was kept constant at $4 \mathrm{~ms}$ following manufacturers instructions and previous tests by the authors.

\section{OPERATING CONDITIONS}

The baseline operating conditions are given in Table 2 . The engine was motored at part load ( 0.5 bar intake pressure) and fired at the same load continuously, i.e. with no skip-firing. The load was defined by setting the throttle position to produce the desired intake pressure. An air-fuel ratio meter was used in the exhaust to measure oxygen content and for setting the correct fuelling for the required engine operating condition. The engine was run with stoichiometric Air/Fuel Ratio (AFR), i.e. equivalence ratio $\Phi=1$, for all the tests presented in the current paper. 100 consecutive cycles of in-cylinder pressure data were acquired after the engine had fired up and had been allowed to stabilise for 20-30 s.

Table 2. Engine Operating Conditions.

\begin{tabular}{|l|c|}
\hline Engine Speed & 1500 RPM \\
\hline Intake Air Pressure & 0.5 bar \\
\hline Injection Pressure & 150 bar \\
\hline Firing mode & Continuous, $\Phi=1$ \\
\hline Ignition Timing & $325^{\circ} \mathrm{CA}$ ATDC \\
\hline Engine-Coolant Temperature & $20^{\circ} \mathrm{C}$ and $90^{\circ} \mathrm{C}$ \\
\hline
\end{tabular}

Synchronization of various control triggers for ignition, injection and camera/laser systems was achieved using an optical encoder mounted on the crankshaft, with 1800 pulses per revolution resolution. This was connected to an AVL Engine Timing Unit (ETU) providing sub-crank angle degree resolution and a $L A B V I E W$ program was used for data acquisition at $0.2^{\circ} \mathrm{CA}$ resolution. Incylinder pressure data acquisition was synchronised with simultaneous crank-angle resolved imaging of natural flame chemiluminescence.

Pressure data acquisition and processing to infer maximum in-cylinder pressure for each cycle $\left(P_{\max }\right)$, crank angle of $P_{\text {max }}$, Indicated Mean Effective Pressure (IMEP), Mass Fraction Burned (MFB), crank angle of $10 \%$ MFB, $50 \%$ MFB, etc., as well as associated Coefficients of Variation (COV), was done using LABVIEW and MATLAB based software.

Fuels: The fuels selected for this study reflect the lack of available published literature on the fundamental behaviour of alcohol fuels inside modern direct injection spark-ignition engines but also the need to compare these with currently used fuels in both commercial and research applications. Table 3 shows a number of selected fuel properties which are relevant to the analysis of spray formation, evaporation characteristics and combustion of these fuels and are given for 1 bar ambient pressure [13-18].

Table 3. Fuel Properties.

\begin{tabular}{|l|c|c|c|c|}
\hline Fuel Properties & Ethanol & Butanol & Gasoline & $\begin{array}{c}\text { Iso- } \\
\text { Octane }\end{array}$ \\
\hline $\begin{array}{l}\text { Density }\left[\mathrm{kg} / \mathrm{m}^{3}\right] \\
\left(20^{\circ} \mathrm{C}\right)\end{array}$ & 0.794 & 0.809 & 0.729 & 0.692 \\
\hline $\begin{array}{l}\text { Viscosity [cP] } \\
\left(25^{\circ} \mathrm{C}\right)\end{array}$ & 1.08 & 3.64 & $0.4-0.8$ & 0.51 \\
\hline $\begin{array}{l}\text { Surface Tension } \\
{[\mathrm{mN} / \mathrm{m}]\left(20^{\circ} \mathrm{C}\right)}\end{array}$ & 22.4 & 25.4 & 25.8 & 14.7 \\
\hline $\begin{array}{l}\text { Latent Heat } \\
{[\mathrm{MJ} / \mathrm{kg}]\left(25^{\circ} \mathrm{C}\right)}\end{array}$ & 0.902 & 0.430 & 0.364 & 0.305 \\
\hline $\begin{array}{l}\text { Energy Density } \\
{[\mathrm{MJ} / \mathrm{kg}],[\mathrm{MJ} / \mathrm{tt}]}\end{array}$ & 29,23 & 37,30 & 44,32 & 45,31 \\
\hline $\begin{array}{l}\left.\text { Boiling Point [ }{ }^{\circ} \mathrm{C}\right] \\
\text { Reid Vapour } \\
\text { Pressure [bar] }\end{array}$ & 78.5 & 117.2 & $30-190$ & 99.8 \\
\hline $\begin{array}{l}\text { Stoichiometric } \\
\text { AFR }\end{array}$ & 9.0 & 11.2 & 14.7 & 15.1 \\
\hline $\begin{array}{l}\text { Research Octane } \\
\text { Number (RON) }\end{array}$ & 129 & 96 & 95 & 100 \\
\hline \begin{tabular}{l} 
H:C, O:C \\
\hline
\end{tabular} & $3,0.5$ & $2.5,0.25$ & $1.92,0$ & $2.25,0$ \\
\hline
\end{tabular}


Injection Strategy: The Injection timing was set for homogeneous mixture preparation mode, i.e. early in the intake stroke, with Start of Injection (SOI) set to $80^{\circ} \mathrm{CA}$ ATDC, in order to maximize the time available for evaporation before ignition. This decision was however balanced by the need to avoid excessive liquid impingement on in-cylinder surfaces, particularly on the piston crown which would affect the imaging arrangement by fouling the windows. It needs to be pointed out here that previous publications by the current authors $[11,12]$ have demonstrated the viability of using split injections, even under early injection homogeneous operating conditions, and the reduction in wall wetting achieved. For the purposes of this paper, such strategies have not been explored using alcohol fuels, although they are of increased relevance with alcohols due to increased cylinder bore oil film dilution [4] and it is expected that more sophisticated strategies will be explored in upcoming publications by our group.

\section{IMAGE ACQUISITION}

High-Speed Camera: A high-speed CMOS camera (Photron APX-RS) was used throughout this study at a frame rate of $9 \mathrm{kHz}$, corresponding to $1^{\circ} \mathrm{CA}$ between frames at 1500 RPM. This was possible with an image resolution of $640 \times 480$ pixels, giving an optical resolution of $\sim 160 \mu \mathrm{m}$ per pixel. The camera was coupled to a 60 $\mathrm{mm}$ Nikon lens with f2.8-28. At this resolution the onboard camera memory allowed just over 100 cycles of data with 60 frames per cycle to be acquired consecutively before data-download to a PC was necessary.

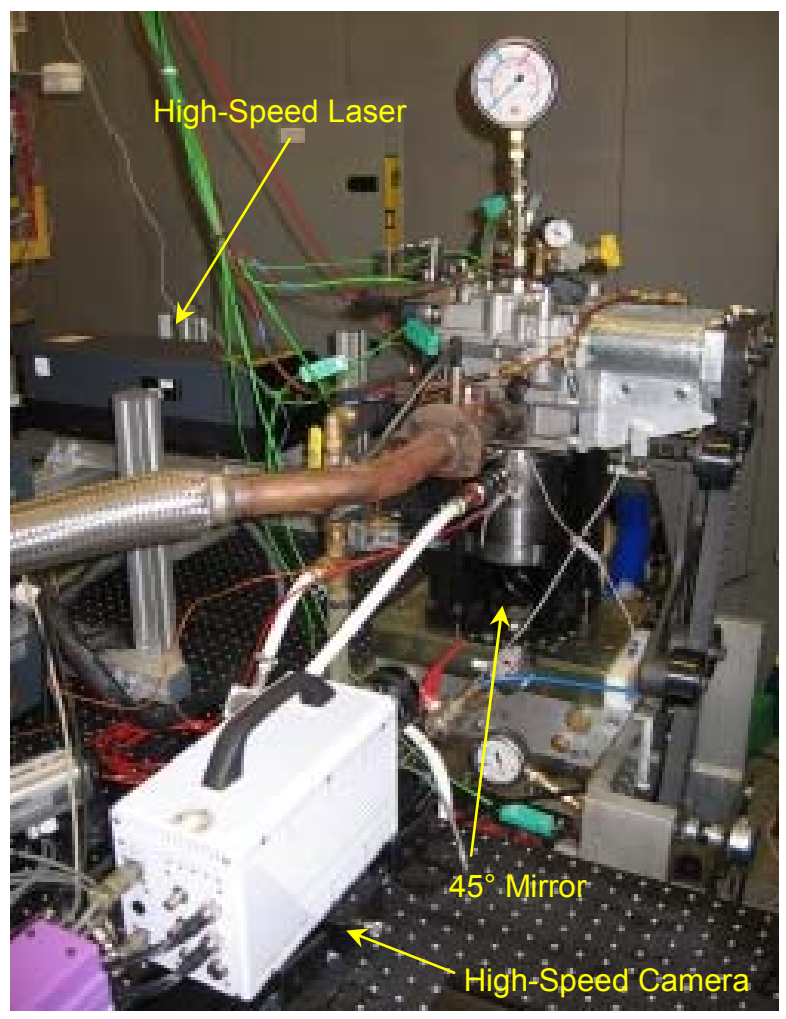

Figure 2. Experimental Set-up for Spray and Flame Imaging through the Piston Crown.

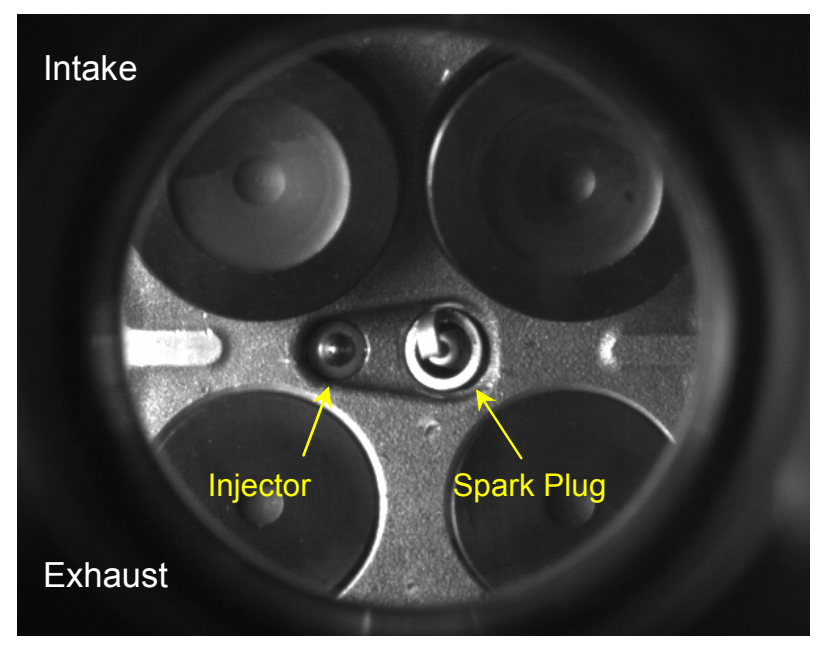

Figure 3. Piston Crown View.

High-Speed Laser: For spray visualization, the combustion chamber was globally illuminated by a New Wave Nd:YLF laser firing at $527 \mathrm{~nm}$ wavelength and entering across the engine in the tumble plane, with two coupled divergent spherical lenses, as illustrated in Figure 2. A white semi-opaque diffuser board was also employed to optimize the Mie-scattering intensity captured. For the tests presented and to guarantee uniform light intensity levels during acquisition runs, the laser was run at high power with both heads firing simultaneously at $9 \mathrm{kHz}$ and synchronised with the camera shutter.

The view shown in Figure 3 was selected for this study as it allowed clear and simultaneous observation of all individual six spray plumes, as well as being the same view used to image flame propagation and therefore providing a relevant plane for the visualization of the initial liquid fuel distribution both during the initial and later stages after fuel injection.

\section{SPRAY DEVELOPMENT}

\section{GENERAL OBSERVATIONS}

Global laser flood-lighting was achieved through the installed pent-roof window and full quartz liner and this allowed illumination of the near-nozzle region, spark-plug region, as well as the length of the engine cylinder and, therefore, the full spray development during and after injection. Spray images were captured through the piston crown window via the $45^{\circ}$ mirror installed inside the hollow extended piston (Bowditch design), typical of optical research engine assemblies.

Typical spray imaging sequences for the duration of the injection period are shown in Figures 4 and 5 for all four fuels investigated: ethanol, butanol, iso-octane and gasoline, using SOI $80^{\circ} \mathrm{CA}$ ATDC under motoring conditions at $1500 \mathrm{RPM}$ using $20^{\circ} \mathrm{C}$ and $90^{\circ} \mathrm{C}$ enginecoolant temperatures; each image is labeled by its crank angle timing following the start of injection, i.e. ${ }^{\circ} \mathrm{CA}$ After Start of Injection (ASOI). The images in Figure 4 were 
enhanced for printing and reproduction purposes, mainly to make the sprays more easily visible to the reader. There will of course be some shot-to-shot variation of the spray development process on a cycle-by-cycle basis but the contribution of the injector to this variation has been shown to be fairly small with current injector [17] and any variations will be mainly due to flow field related variability, which will not be discussed in detail in this paper; see $[11,12]$ for more information. It should be noted that for the purposes of this motoring investigation it was decided to use the same fuel pulse-width for all fuels $(0.8 \mathrm{~ms}$, corresponding closely to stoichiometric airfuel ratio for iso-octane at the current operating conditions). This allowed both the full injection period and post-injection periods to be analysed directly for all fuels and thereby allow the investigation of the behaviour of the sprays as they interact with - on average - the same flow field. However, for the combustion tests shown later in the paper, the fuel pulse widths were adjusted to achieve correct stroichiometric operation with each respective fuel. From Table 3 it can be seen that for alcohols this results in an increase in the necessary fuel pulse width as a result of the lower AFR of these two fuels.

In general, for the cold operating conditions shown in Figure 4 , the four fuels were seen generally to exhibit similar development and break-up behaviour up to the end of injection which was $\sim 11^{\circ} \mathrm{CA}$ ASOI or $91^{\circ} \mathrm{CA}$ ATDC. The directionality of the spray plumes was close to the injector design requirements as illustrated by the schematic shown on Figure 1, although some spray/flow interactions were seen particularly with respect to spray plumes 1 and 6 , which due to their nozzle angles are more susceptible to direct interactions with the flow over one of the intake valves. For the hot operating conditions with the engine head at $90{ }^{\circ} \mathrm{C}$, the fuels could generally be grouped into two groups, those which experienced spray collapse (ethanol and gasoline) and those which did not (butanol and iso-octane) as described in the following sections.

For the purposes of clarity and in order to facilitate the discussion of the observed characteristics of spray development for all the fuels tested, the text below has been broken down into three main sections, a section on the early injection stage, one on the fully-developed injection stage and a final section on the post-injection mixing stage.

Early Injection Stage: One clear difference between the fuels can be seen in the time taken for fuel to arrive at the injector tip. At $3^{\circ} \mathrm{CA}$ ASOI in Figure 4 there is no fuel seen at the injector tip for both the alcohol fuels although for iso-octane and particularly gasoline there are visible signs that the spray tips are beginning to exit the nozzles with penetrations of $\sim 1 \mathrm{~mm}$. The effect of this delay is more clearly seen in the next frame, at $4^{\circ} \mathrm{CA}$ ASOI. Here the sprays of ethanol and butanol are visibly less developed and exhibit a smaller spray-tip penetration than those of iso-octane and gasoline (a result of this delay which corresponds to $<50 \mu$ s from tests conducted with the current injector/driver system). The butanol spray is the slowest to arrive at the injector tip and the effects are replicated to a similar extent at the higher engine coolant temperature of $90{ }^{\circ} \mathrm{C}$ discussed later. This phenomena is hypothesized to stem from the different fluid dynamic properties of the four fuels (details of which can found in Table 3), in particular, density, viscosity and surface tension. Timing errors were ruled out after extensive and repetitive testing all fuels with different pulse widths and testing the driver system with another similar injector. Confidence in the robustness of the driver system performance is also strong due to the $100 \%$ repeatability of the timing of fuel arrival at the injector tip recorded during all the tests and the experience gained from initial hardware performance characterization, details of which can be found in [17].

Figure 5 shows the spray development for all fuels at $90{ }^{\circ} \mathrm{C}$ engine coolant temperature. The presence of liquid fuel can be seen at the injector tip for all fuels at $3^{\circ}$ $\mathrm{CA}$ ASOI i.e. $1^{\circ} \mathrm{CA}$ earlier for ethanol and butanol than at $20^{\circ} \mathrm{C}$ engine coolant temperature. The effect of temperature is clearly affecting internal injector and innozzle dynamics to some extent, quantified by a faster time to 'first fuel seen' at the injector tip. At $3^{\circ} \mathrm{CA}$ ASOI the six individual spray plumes are just visible in the images for ethanol and butanol and are slightly more developed for iso-octane and gasoline. Previous work using the same type of gasoline and the same injector in this engine [11, 12] has shown that the gasoline spray collapses in the engine under low pressure and high temperature conditions (namely 0.5 bar ambient pressure and $90{ }^{\circ} \mathrm{C}$ engine head temperature). In Figure 5 and at $3^{\circ} \mathrm{CA}$ ASOI the spray plumes are clearly 'swollen' and the emerging spray is already visibly collapsed for gasoline; in contrast, the spray plumes for ethanol are clearly spaced out at $3^{\circ} \mathrm{CA}$ ASOI, although subsequent spray development also showed a degree of spray collapse. The ethanol spray did not collapse immediately out of the nozzles and this is consistent with previous work by the current authors which showed that in-nozzle boiling and subsequent spray collapse is driven not just by the presence of highly volatile components in a fuel but by the level of superheat experienced by these [18].

The initial spray development process for butanol is not greatly affected at $90{ }^{\circ} \mathrm{C}$ engine head temperature. The spray does not collapse like gasoline and behaves more like iso-octane at $20^{\circ} \mathrm{C}$, with wider plumes and faster penetration. Similar trends were observed for the initial behaviour of iso-octane sprays when comparing the transition from a cold engine head temperature of $20^{\circ} \mathrm{C}$ to a fully warm of $90{ }^{\circ} \mathrm{C}$, although the effects were accentuated relative to butanol due to the close proximity of iso-octane's boiling point to the injector body temperature. No immediate spray collapse was observed for iso-octane under the present test conditions, which is again consistent with previous work in the same engine $[11,12]$. 


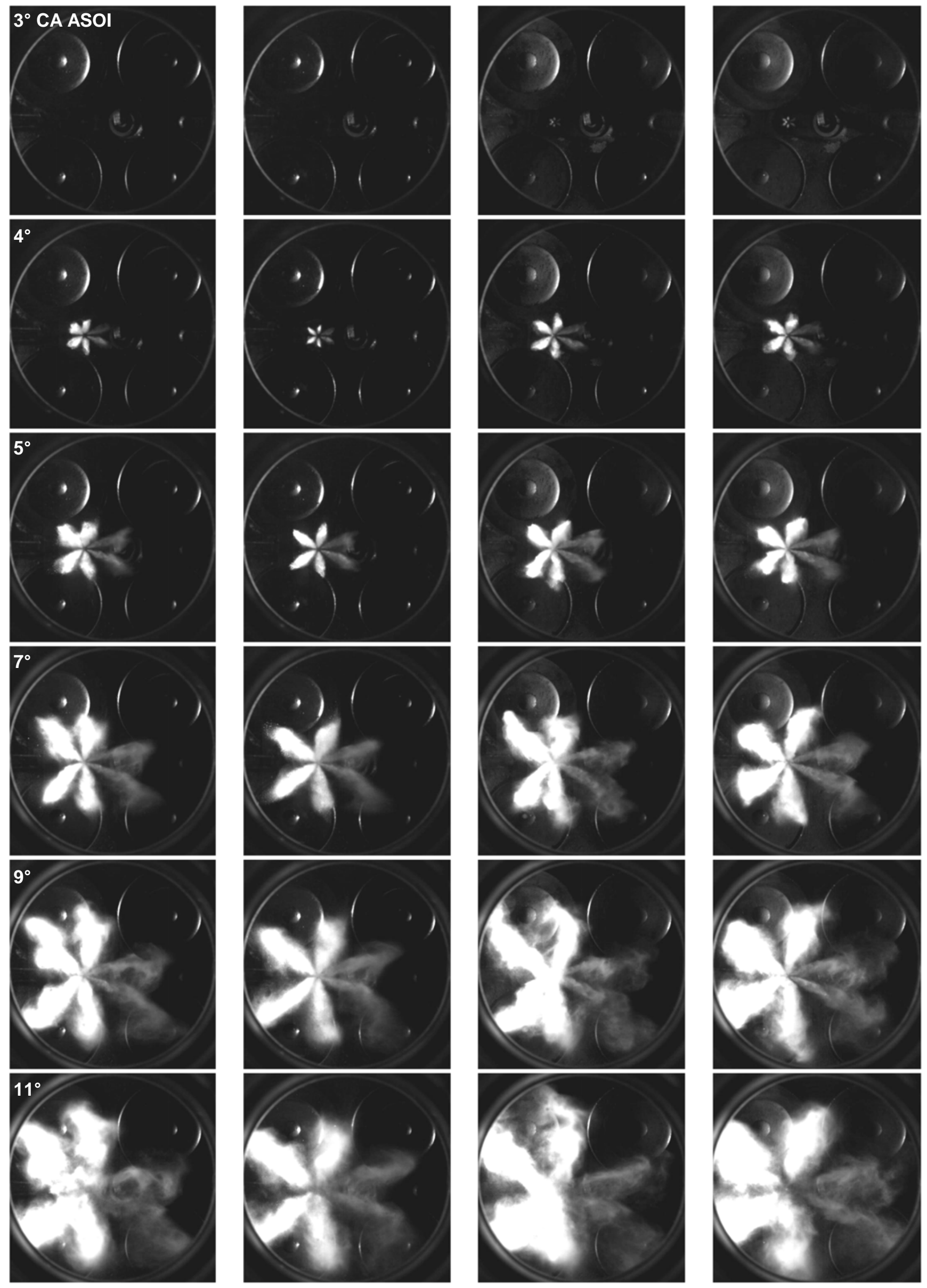

Figure 4. Spray Development: Column1 Ethanol, Column 2 Butanol, Column 3 Iso-Octane, Column 4 Gasoline (Engine Head $20^{\circ} \mathrm{C}$, SOI $80^{\circ} \mathrm{CA}$ ATDC). 


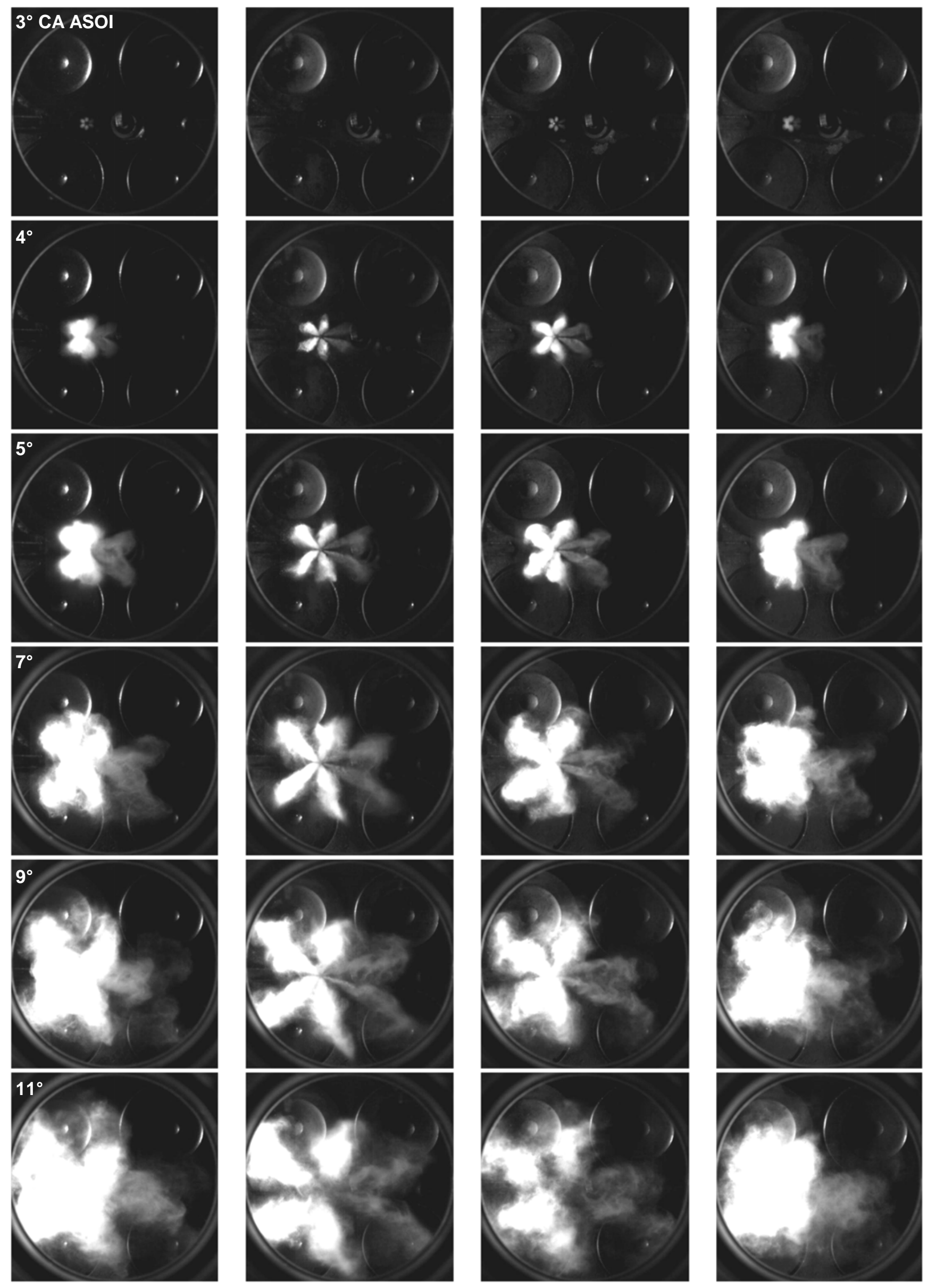

Figure 5. Spray Development: Column1 Ethanol, Column 2 Butanol, Column 3 Iso-Octane, Column 4 Gasoline (Engine Head $90^{\circ} \mathrm{C}$, SOI $80^{\circ} \mathrm{CA}$ ATDC). 
Main Injection Stage: The same fluid properties that affect the time to first fuel seen at the injector tip are also responsible for the characteristics of spray development and evaporation of each fuel. Observations of cycle-bycycle images showed that butanol is clearly the most poorly atomized fuel at $20{ }^{\circ} \mathrm{C}$ with no major droplet 'clouds' around the spray plumes and good definition of each individual plume in the first $7^{\circ} \mathrm{CA}$ ASOI. The individual plumes are also visually thinner, i.e. have smaller cone angles, immediately after start of injection, and are more compact than those of the other three fuels, possibly as a result of butanol's high viscosity and surface tension. After $7^{\circ}$ CA ASOI butanol shows increased levels of air entrainment along the length of the individual spray plumes and there are increased similarities to the sprays of ethanol. The effect is seen predominantly around the spray tips; this appears to occur as the effect of drag 'flattens' the plume-tips forcing spray break-up such that droplets in this region are transported away by outward recirculating vortices set up as a result of shear forces along the plume axis. The increased levels of air entrainment and global sprayflow interactions enhance the droplet evaporation rate and result in visibly higher levels of droplet 'clouds' around the spray-air interfaces, ultimately breaking-up the spray. The different levels of drag and rates of transport of droplets away from the leading edge are both dictated by local conditions and fluid properties and, are thus believed to be the main mechanisms governing the observed differences in spray development for each of the tested fuels. Similar mechanisms for spray breakup from multi-hole atomizers using standard fuels such as gasoline have been reported in [19-21].

At $20{ }^{\circ} \mathrm{C}$, ethanol and gasoline appear to exhibit the largest cone angles immediately after start of injection, followed by iso-octane and then butanol, although these have not been directly quantified at this stage and no relevant literature has been found to compare these against, particularly for multi-hole injectors. Subsequent spray development and plume break-up appear to have more comparable characteristics for ethanol, iso-octane and gasoline than for butanol. In general it appears that gasoline produces the widest plumes during injection, probably as a result of the high volatility components in the fuel, some of which are close to their boiling point temperatures even at $20{ }^{\circ} \mathrm{C}$ as a result of subatmospheric conditions $(0.5$ bar intake manifold pressure) and therefore 'swell' the plumes due to increased vapour generation within the liquid (i.e. bubbling). However, fluid properties like viscosity are likely to have a major influence on the speed at which the spray breaks up and subsequent interaction with the flow occurs, both which will affect the developed cone angle of the spray plumes. These effects should be borne in mind when reading the discussion of calculated 'projected spray areas' presented in later sections.

At $90{ }^{\circ} \mathrm{C}$, there were clearly marked differences in the behaviour of the four sprays. Although the effects for isooctane and gasoline have been recently reported by the current authors [11, 12], here these effects are compared directly to the alcohol fuels. Ethanol is clearly seen to develop a partially 'collapsed' spray, a term used to describe the effect of flash boiling on the spray development as a result of the loss of outward radial momentum (in the direction intended by the internal geometry and angles of the nozzle holes); this was seen to affect gasoline to a greater extent as a result of the number of chemical components experiencing a higher degree of superheat.

Analysis of subsequent crank-angle timing ASOI reveal significant changes in the development and atomization behaviour of ethanol and gasoline at $90^{\circ} \mathrm{C}$. The intended spray geometry for these two fuels is clearly destroyed, with plumes 2-5 (as shown in the schematic of Figure 1) being drawn towards the central axis of the injector and merging into a large plume producing a 'cloud' of smaller diameter droplets in this region. This is also reflected in the larger levels of Mie-scattered intensity recorded in comparison to the levels at $20{ }^{\circ} \mathrm{C}$. Droplet size measurements on a static rig with the same injector confirmed this trend [22] and similar results have also been reported using both multi-hole and pressure-swirl injectors for DISI engines [21, 23, 24]. From the images corresponding to $7^{\circ} \mathrm{CA}$ ASOI, it can be seen that this 'spray collapse' appears stronger for gasoline than for ethanol, demonstrated by the 'cross-shape' made by the ethanol plumes and also consistent with the less 'hazy' shape of the spray observed for ethanol at $3^{\circ} \mathrm{CA}$ ASOI in comparison to gasoline, suggesting that the plumes still retain some of their original angular momentum. As mentioned already it is likely that the significant levels of superheat for some components in the gasoline are responsible for the increased levels of collapse observed and also for the reduced density of the droplet cloud seen around the main 'central' plumes as a result of faster evaporation. The two other plumes (plumes 1 and 6 with reference to Figure 1) have a higher nozzle turning angle and are also seen to be affected for both ethanol and gasoline. By $\sim 7^{\circ} \mathrm{CA}$ ASOI these are no longer distinguishable as two separate plumes, having merged into a single plume with significantly reduced radial penetration. The effect of nozzle angles and specific geometries have also been reported to affect the internal flow of the injector and the levels of fuel atomization arising from different cavitation regimes inside the nozzles [25-27].

The effects of increased engine head temperature for butanol and iso-octane are not nearly as dramatic as for ethanol and gasoline, but a noticeable increase in both cone angle and level of evaporation at the spray-air interfaces can be observed. Specifically, the effects can be seen immediately after the start of injection as a reduction in the spacing between the individual plumes and more clearly after $\sim 7^{\circ} \mathrm{CA}$ ASOI as the increased levels of scattering intensity around the main plumes.

Post-Injection Mixing Stage: Under cold engine operation $\left(20{ }^{\circ} \mathrm{C}\right.$ engine head temperature), the post-injection stage (after $\sim 11^{\circ} \mathrm{CA} \mathrm{ASOI}$ ) is characterised by varying 
levels of piston impingement, mixing and evaporation for all fuels. Analysis of the spray development images showed that that by $\sim 11^{\circ} \mathrm{CA}$ ASOI on average, direct fuel impingement by plumes $2-5$ occurred on the piston crown for all fuels but to varying extents. Phenomena such as droplet 'bounce' and 'splash' across the piston top therefore contributes to the mass of evaporating charge in the cylinder as a result of re-atomized and reentrained droplets into the cylinder flow, as described by classical impingement models [28, 29]. Such models highlight fluid properties (particularly viscosity), as well as impact angle and velocity, as the governing parameters that influence the likely outcome of a droplet impact, i.e. whether a droplet will stick to the piston surface or be reatomized and re-entrained into the flow for example. Indeed, after the engine motoring tests using butanol, the piston crown was seen to be largely covered in a 'thick' fuel film to the extent that the piston crown window had to be cleaned due to visual distortion produced after only $\sim 20-30$ cycles of continuous motoring operation at $20^{\circ} \mathrm{C}$ engine head temperature. In this case it was therefore not possible to acquire 100 sprays from 100 consecutive cycles and several batches of smaller numbers of cycles were acquired, in between which the windows and cylinder surfaces were cleaned. Due to the high viscosity of butanol and the presence of a non-evaporating fuel film on the piston crown, even engine motoring using skip-injections was found to be unsuitable in maintaining the imaging windows clean. In comparison, the sprays of iso-octane and gasoline, which both have lower densities and viscosities than butanol but more importantly lower boiling points, appeared to break up more efficiently and produced lower levels of piston surface impingement. Ethanol sprays also appeared to interact more heavily with the flow field and significant spray tip break up is clearly observed in Figure 4 . The lower viscosity and surface tension of the latter three fuels allowed imaging runs to be acquired in batches of 100 consecutive engine cycles which greatly facilitated the testing schedule and procedure. During the hot motoring engine runs $\left(90{ }^{\circ} \mathrm{C}\right.$ engine head temperature), fuel films on the piston crown were also significantly reduced with butanol (but not eliminated), to the extent that image acquisition for a batch of 100 consecutive engine cycles was actually possible.

\section{SPRAY AREA ANALYSIS}

The observed spray effects are quantified from the acquired spray images in graphs of mean 'projected' spray areas calculated for the full injection event and post-injection timings (up to $25^{\circ} \mathrm{CA}$ ASOI), for 100 motoring engine cycles. These are shown in Figure 6 for the $20^{\circ} \mathrm{C}$ engine head temperature. All spray areas are plotted normalised to the piston-crown window area, such that 0.7 on the $y$-axis refers to $70 \%$ of the pistoncrown window area. The ratio of the piston-crown window area to the full cylinder bore area is $\sim 0.55$, with the optical piston-crown diameter corresponding to $\sim 0.73$ of the full-bore diameter, i.e. $70 \%$ of the piston-crown window area corresponds to $\sim 40 \%$ of the engine full-bore area.
The calculation of spray areas was achieved by binarising the raw spray images. A truly representative image binarisation process relies on a selection of an intensity threshold value which defines which pixels in the image are effectively considered to represent liquid fuel spray and those which are considered to represent the image background. In order to achieve high levels of accuracy therefore one relies on a source image which has high gradients of intensity defining the object of interest, in this case that of a fuel spray. Unfortunately, a spray imaged with Mie-scattering technique rarely exhibits such qualities in an engine, and the image is instead composed of high intensity regions i.e. regions of high concentration of liquid fuel (since scattering intensity is proportional to liquid droplet surface area) and gradually lower intensity regions e.g. at the periphery of a spray. Furthermore, the illuminated spray acts as a light source itself and scatters light in all directions producing some secondary reflections off engine surfaces. The process of selecting a particular threshold value to describe the true 'spray envelope' is therefore not trivial and depends effectively on the properties of each image histogram. A number of different imaging thresholding strategies were thus attempted to examine the sensitivity of the current images to changes in the threshold values. Specifically, image processing to increase the levels of contrast were attempted as well as using different threshold values on the unmodified raw images. Although different magnitudes of spray areas were obtained for different strategies, depending on the intensity threshold sensitivity of each, the trends between the four fuels always remained the same. As a result, it was decided to threshold the unmodified raw images only, as there was a relatively high signal to noise level in the imaging arrangement; this was demonstrated by the high final threshold value chosen. Specifically, a threshold of 35/255 was used so that not only the high intensity liquid core of the fuel spray was captured but also the 'lighter' regions of droplet clouds around the spray plumes. This value was used for all the fuels and all crank-angle intervals to allow more direct relative comparisons of both spray development and evaporation to be carried out. The number of pixels falling within this threshold, were counted for each imaged frame and for 100 cycles, to produce the mean curve shown in Figure 6 . The first measurement of area is seen to occur at $3^{\circ}$ $\mathrm{CA} A S O \mathrm{I}$ and this relates to the initial delay of fuel arrival at the injector tip.

Figure 6 shows that the spray development for gasoline and iso-octane was very similar at $20^{\circ} \mathrm{C}$ engine coolant temperature and this is reflected in the spray areas which show similar growth rates and peaks at end of injection $\sim 11^{\circ} \mathrm{CA}$ ASOI. After the end of injection, the spray areas for iso-octane reduce markedly faster than for gasoline, resulting in a $60 \%$ reduction in spray areas with respect to their peak values compared to only $\sim 20 \%$ reduction for gasoline at $25^{\circ} \mathrm{CA}$ ASOI. For the alcohol fuels, the growth rates of spray areas were lower than for both iso-octane and gasoline, showing peak values at end of injection $10 \%$ lower for ethanol and $20 \%$ lower for butanol relative to the levels of the two former fuels. The 
post injection period for the two alcohols showed similar behaviour to the gasoline at $20{ }^{\circ} \mathrm{C}$ with consistently higher spray areas calculated than those for iso-octane. This long 'tail' in the scattering intensity was also reported for gasoline in previous work by the same authors [11] and was expected for butanol due to its high boiling point $\left(\sim 117^{\circ} \mathrm{C}\right)$; the same result for ethanol was initially surprising however. Visual analysis of the images revealed that the prolonged and higher scattering intensities for ethanol, in comparison to the rest of the single-component fuels, were indeed real and not an artefact of the image processing, and examples of the levels of scattering intensity at $25^{\circ} \mathrm{CA}$ ASOI are shown in Figure 7 for ethanol, butanol, iso-octane and gasoline. One hypothesis for this observed effect could be ethanol's much higher latent heat of vaporization (902 $\mathrm{kJ} / \mathrm{kg}$, Table 3) compared to iso-octane's (305 kJ/kg, Table 3) for example, which is likely to result in significantly higher levels of charge cooling. The temperature drops associated with charge cooling, which can be as much as 30-40 K [21], have long been recognized as one method of reducing in-cylinder charge temperatures to avoid knocking and is the reason why DISI engines are able to operate at higher compression ratios. However, in a motoring DISI engine, where there is no residual heat from combustion products in the cylinder, the high levels of charge cooling with ethanol [5] may result in a reduction in the evaporation rate, as indicated by Figures 6 and 7 .

At $90{ }^{\circ} \mathrm{C}$ engine coolant temperature the start of injection period was very similar for the tested fuels in terms of spray areas, apart from butanol which showed slower initial growth rates. This similarity does not necessarily mean a similar spray development however, since spray development effects can contribute to produce the same spray areas e.g. a collapsed spray could have the same area in principle as a non-collapsed spray. The injection period on the graphs should therefore be interpreted relative to the images in order to de-couple such effects. The spray area graphs can only be interpreted in isolation after the end of injection, that is after the effect of any existing spray structure has disappeared and where only the field of droplet clouds contributes to the Mie-scattering process.

The peak values of spray area were highest for ethanol, gasoline, butanol and iso-octane respectively. Partial spray collapse for ethanol increased the measured peak spray areas by $20 \%$ over those measured at $20^{\circ} \mathrm{C}$ due to a wider scattering area; while the spray areas $25^{\circ} \mathrm{CA}$ ASOI were $\sim 8 \%$ lower due to increased evaporation rates. Gasoline sprays experienced higher levels of spray collapse than ethanol at $90{ }^{\circ} \mathrm{C}$, resulting in peak spray areas which were marginally lower than those measured at $20{ }^{\circ} \mathrm{C}$ by $\sim 6 \%$; the effect of reduced outward radial momentum of the spray plumes was responsible for this difference. The spray areas $25^{\circ} \mathrm{CA}$ ASOI however were reduced significantly, by $\sim 50 \%$ relative to those at $20^{\circ} \mathrm{C}$, highlighting the effect of faster evaporation rates of the low boiling point fractions in the gasoline fuel.

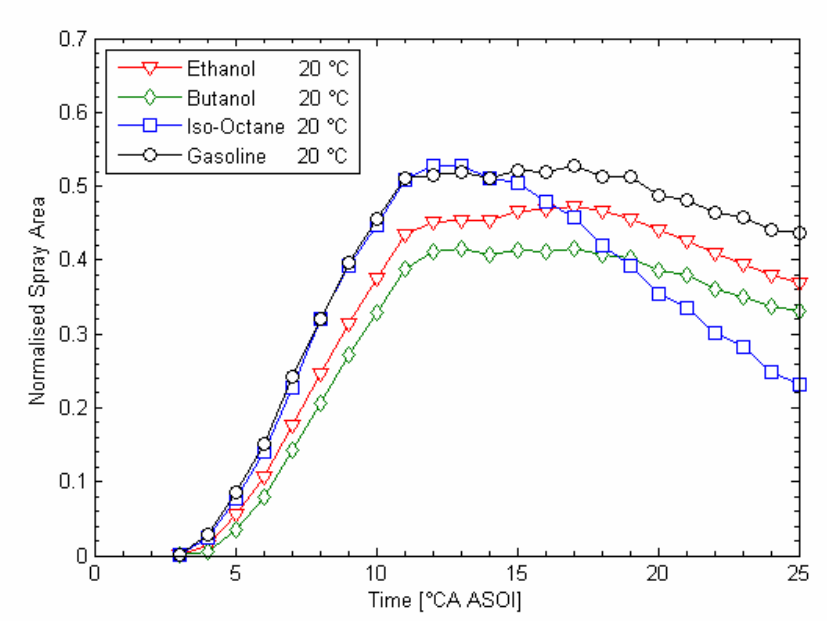

Figure 6. Spray Areas, Engine Head at $20^{\circ} \mathrm{C}$.

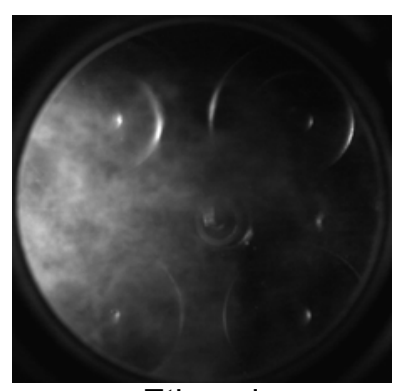

Ethanol

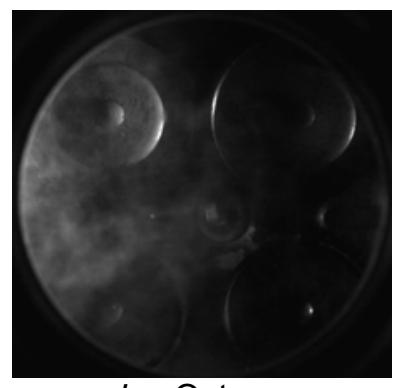

Iso-Octane

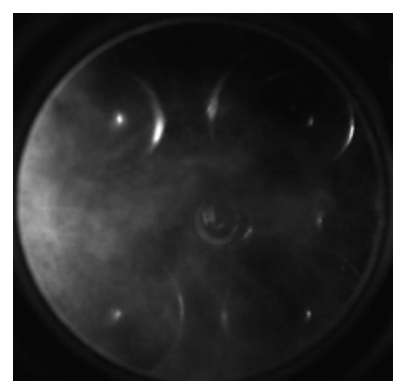

Butanol

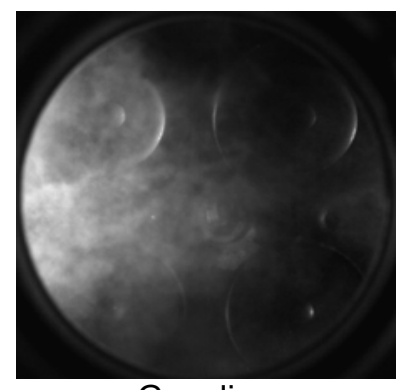

Gasoline
Figure 7. Images of Mie-Scattering at $25^{\circ} \mathrm{CA}$ ASOI, Engine Head $20^{\circ} \mathrm{C}$.

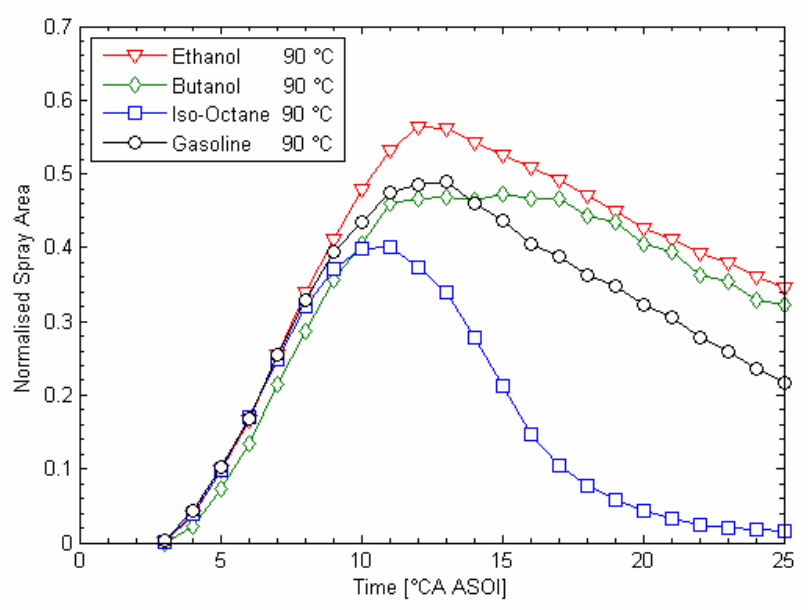

Figure 8. Spray Areas, Engine Head at $90^{\circ} \mathrm{C}$. 
The peak spray areas for butanol at $90{ }^{\circ} \mathrm{C}$ were higher than those at $20{ }^{\circ} \mathrm{C}$ by $\sim 10 \%$, illustrating the effect of swelling of the spray plumes and were similar to those calculated for gasoline at this temperature; the period after end of injection showed a faster rate of decline in terms of spray areas, highlighting the increased effect of temperature on the spray's evaporation, resulting in spray areas at $25^{\circ} \mathrm{CA}$ ASOI that were similar to those calculated at $20^{\circ} \mathrm{C}$. Iso-octane is the only fuel that shows a large change in behaviour post-injection at $90^{\circ} \mathrm{C}$. The peak value of spray area is reduced by $25 \%$ from the peak at $20{ }^{\circ} \mathrm{C}$ and this effect continues even after the end of injection, with rapidly decreasing spray areas that become nearly zero by $25^{\circ} \mathrm{CA}$ ASOI.

\section{COMBUSTION}

\section{IN-CYLINDER PRESSURE DATA}

Synchronised in-cylinder pressure logging and flame imaging was carried out to investigate the differences in pressure histories of each fuel and gain an insight into the different characteristics of the combustion of alcohols versus those of gasoline and iso-octane. The fuel pulse widths were adjusted from those used in the motoring spray development investigation $(0.8 \mathrm{~ms})$ to allow

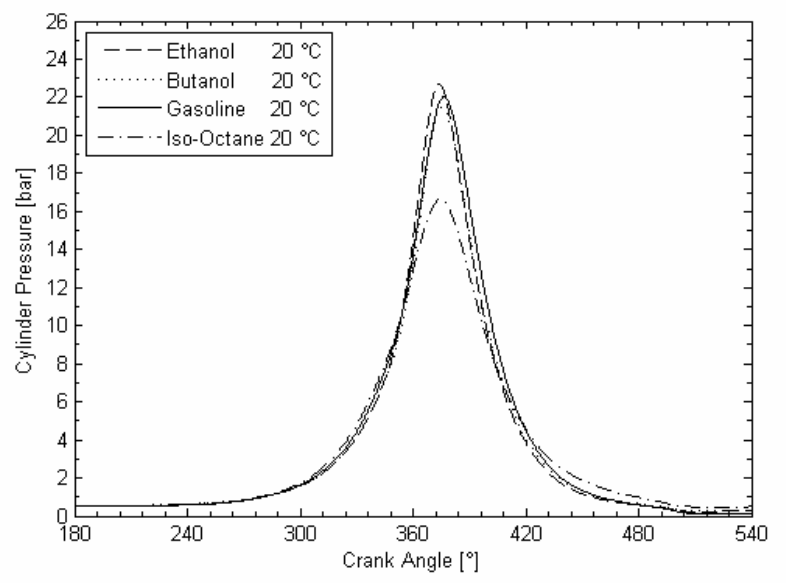

Figure 9. In-Cylinder Pressure, $20^{\circ} \mathrm{C}$.

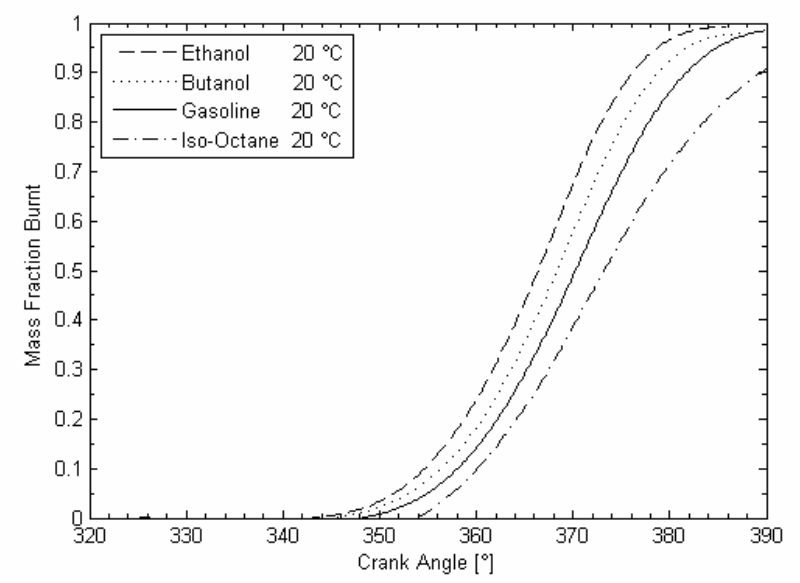

Figure 10. Mass Fraction Burnt, $20^{\circ} \mathrm{C}$. stoichiometric operation at the test condition selected. A fixed ignition timing of $35^{\circ} \mathrm{CA}$ before compression TDC (or $325^{\circ}$ CA ATDC, Table 2) was used for this initial characterization of all fuels, corresponding to gasoline's Minimum spark advance for Best Torque (MBT). The fuel pulse widths used were $1.3 \mathrm{~ms}$ for ethanol, $1.1 \mathrm{~ms}$ for butanol, $0.85 \mathrm{~ms}$ for iso-octane and $0.9 \mathrm{~ms}$ gasoline.

The mean in-cylinder pressure traces and associated curves of MFB are shown for all fuels in Figures 9-12 and for both $20^{\circ} \mathrm{C}$ and $90{ }^{\circ} \mathrm{C}$ engine coolant temperature (engine head and metal liner).

Engine operation at $20{ }^{\circ} \mathrm{C}$ engine coolant temperature produced the highest in-cylinder pressure $\mathrm{P}_{\max }$ (averaged over 100 cycles) using ethanol (22.9 bar), followed by gasoline (22.3 bar), then butanol (21.8 bar) and finally iso-octane (16.8 bar). The data are summarised in Table 4. Similar trends were found for the phasing of mass fraction burned, with ethanol exhibiting the fastest combustion; however, butanol showed an overall faster MFB than gasoline, the result of which is also visible in the slightly more advanced position of $\mathrm{P}_{\max }$ obtained relative to gasoline. The small difference in $\mathrm{P}_{\max }$ between these two fuels makes it likely that using some ignition retard for butanol will result in similar $P_{\max }$ and crank angle of $P_{\max }$ (phasing) to that obtained with gasoline.

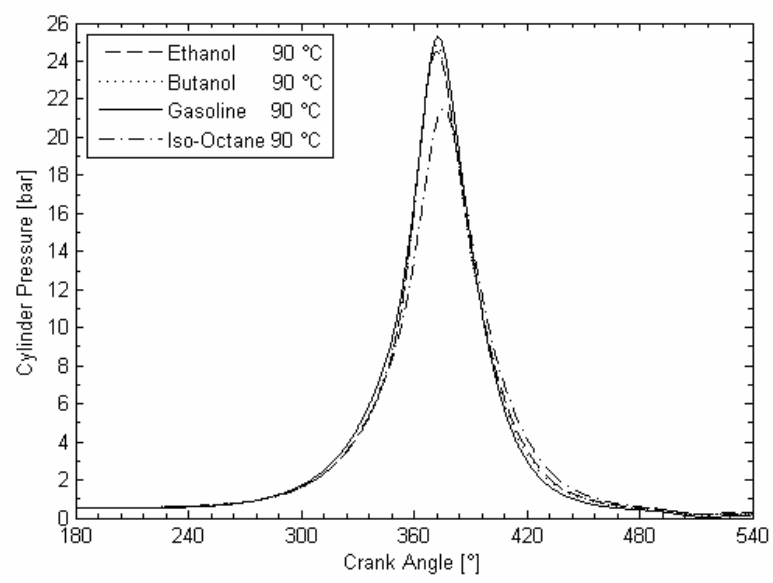

Figure 11. In-Cylinder Pressure, $90^{\circ} \mathrm{C}$.

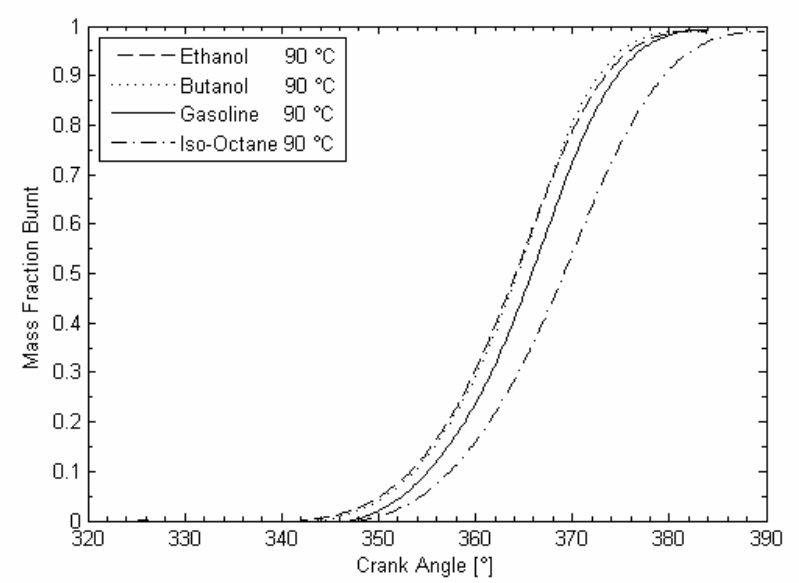

Figure 12. Mass Fraction Burnt, $90^{\circ} \mathrm{C}$. 
Iso-octane exhibited a significantly lower $\mathrm{P}_{\max }$ (16.8 bar) compared to the other fuels and this is also reflected in the slower MFB curve. This result is similar to that obtained in previous tests [11]. The spread of $P_{\max }$ was also seen to be lower for ethanol which resulted in lower values of variability in $\mathrm{P}_{\max }$ and IMEP. Iso-octane showed the highest level of scatter in these parameters. Typical values of $P_{\max }$ and $\mathrm{COV}_{\mathrm{P}_{\max }}$ are shown in Table 4 for the four fuels at the two engine temperatures.

Table 4. In-Cylinder Pressure Statistics.

\begin{tabular}{|c|c|c|c|c|c|c|}
\hline \multirow{3}{*}{ Fuel } & \multicolumn{6}{|c|}{ Engine Temperature } \\
\hline & \multicolumn{3}{|c|}{$20^{\circ} \mathrm{C}$} & \multicolumn{3}{|c|}{$90^{\circ} \mathrm{C}$} \\
\hline & $\begin{array}{l}P_{\max } \\
\text { [bar] }\end{array}$ & $\underset{[\%]}{\mathrm{COV}_{P_{\max }}}$ & $\begin{array}{c}\theta \times \mathrm{xb} 50 \% \\
{\left[{ }^{\circ} \mathrm{CA} \text { AIT }\right]}\end{array}$ & $\begin{array}{l}P_{\max } \\
\text { [bar] }\end{array}$ & $\begin{array}{c}\mathrm{COV}_{\mathrm{Pmax}_{\max }} \\
{[\%]}\end{array}$ & $\begin{array}{c}\theta \times \mathrm{xb} 50 \% \\
{\left[{ }^{\circ} \mathrm{CA} \text { AIT }\right]}\end{array}$ \\
\hline Ethanol & 22.9 & 8.2 & 41.3 & 24.8 & 6.0 & 39.1 \\
\hline Butanol & 21.8 & 9.6 & 43.3 & 25.2 & 5.5 & 39.3 \\
\hline Gasoline & 22.3 & 6.0 & 45.2 & 25.6 & 5.2 & 40.8 \\
\hline Iso-Octane & 16.8 & 11.6 & 48.1 & 21.8 & 7.9 & 44.1 \\
\hline
\end{tabular}

The pressure trace can also reveal details about the levels of charge cooling from each fuel. At $20{ }^{\circ} \mathrm{C}$ it appears that between $300-325^{\circ}$ CA ATDC, i.e. after intake valve closure but before ignition timing, the pressure of iso-octane rises above that of the other fuels marginally. The second highest pressure is that of gasoline with very little difference between the alcohols. Given the higher latent heat of evaporation of both ethanol and butanol relative to iso-octane and gasoline (Table 3), it is likely that higher levels of charge cooling for alcohol fuels reduce the intake charge temperatures below those of iso-octane, such that compression pressures are marginally lower before ignition. It should also be noted that motoring pressures for these tests were also on average higher using the metal watercooled liner than those with the full quartz liner in [11].

\section{FLAME IMAGING}

In order to study the observed spray effects with respect to combustion for the different fuels, an imaging study of combustion was carried out for a batch of 100 consecutive cycles. The operating conditions are summarised in Table 2, and it is again noted that the ignition timing used was the same for all fuels. This was a conscious decision and allowed comparison of the fundamental behaviour of flame growth for each fuel under the same initial local in-cylinder conditions of pressure and temperature. The flames of different fuels however, have different laminar burning velocities and this will affect the phasing of $P_{\max }$. A future study will therefore focus on optimizing the ignition timing for each fuel by performing full 'mapping' at this operating point, in order to achieve the same phasing of $\mathrm{P}_{\max }$ or the same phasing of a specific percentage of MFB (typically 50\%) for all fuels.

Time-resolved flame growth is shown in Figure 13 for several crank angle degrees After Ignition Timing $\left({ }^{\circ} \mathrm{CA}\right.$ AIT) for all fuels with engine coolant temperature $20^{\circ} \mathrm{C}$ (head and liner). The flame images are shown with optimized contrast levels such that they are more easily seen on printed paper. However, they were enhanced by the same amounts to allow comparisons of luminosity across fuels for each crank angle set shown. Gasoline showed the highest flame luminosity in the initial and late combustion stages followed by butanol and then ethanol. Ethanol was observed to have the fewest number of bright spots, which can be typically associated with the diffusion burning of liquid droplets. Both alcohol flames also had noticeably different visual characteristics than iso-octane and gasoline flames, with a more 'foggy' appearance, exhibiting less contrast within the flame and a less wrinkled, textured feel. Flame growth was observed to be typically faster with ethanol, followed closely by gasoline and butanol. Although iso-octane flames grew in similar shapes and directions to those of gasoline, their growth was significantly slower and there appeared to be room for optimizing the ignition timing to achieve similar rates of flame growth to the other fuels.

In order to assess the average time-resolved rate of flame growth and the direction of flame propagation for each fuel, flame areas were obtained on a cycle-by-cycle basis via binarisation of each flame image. Since no image intensifier was used for the current study, acquired flame chemiluminescence intensities were quite low during the initial phase of combustion $\left(0-15^{\circ} \mathrm{CA}\right.$ AIT). However, as a result of the low levels of background noise i.e. the good contrast between the flames and the background, it was possible to enhance the images to improve contrast. This process also resulted in reducing the sensitivity of the intensity value used in the thresholding operation which effectively standardised the processing methodology for all flames. The methodology was visually checked 'on-line' for each flame to ensure that no overestimation of the flame areas was occurring during the whole period of flame growth. The flames were therefore processed with a final threshold of 20/255. Additionally, the centroid of area for each flame was identified in $X$ and $Y$ co-ordinates in order to allow quantitative comparisons of flame growth and motion between the different fuels and for different engine coolant temperatures.

It can be seen from the flame images shown in Figure 13 that typically flames are 'clipped' by the boundaries of the optical piston crown from $\sim 30^{\circ} \mathrm{CA}$ AIT onwards. The following discussion should therefore bear in mind that a degree of masking will be introduced in the quantification of the flames which get convected towards the cylinder walls by the tumble motion, relative to those that grow more centrally around the spark plug. 


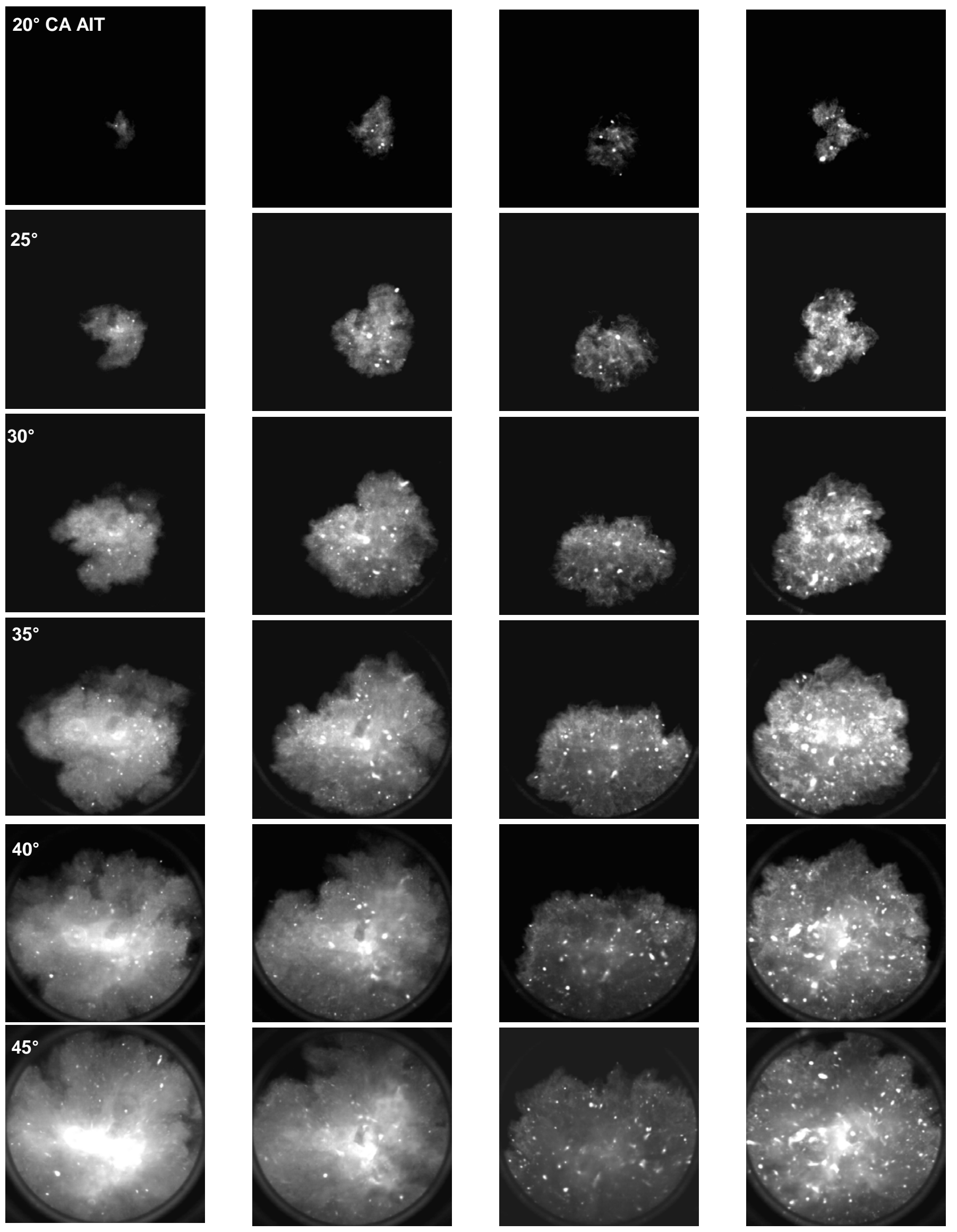

Figure 13. Fame Growth: Column 1 Ethanol, Column 2 Butanol, Column 3 Iso-Octane, Column 4 Gasoline (Engine Head and Liner Coolant $20^{\circ} \mathrm{C}$ ). 


\section{FLAME GROWTH AND MOTION}

Flame Growth: The growth in flame size is plotted for all fuels in terms of an equivalent radius in Figures 14-15, calculated from the flame areas of all individual cycles on the basis of a circle with the same area to that of each flame. The flame radius is used here as an additional metric to the mass fraction burned since it can reveal details about flame growth phenomena immediately after ignition on a cycle-to cycle basis, a period which is not resolved well by thermodynamically derived MFB data.

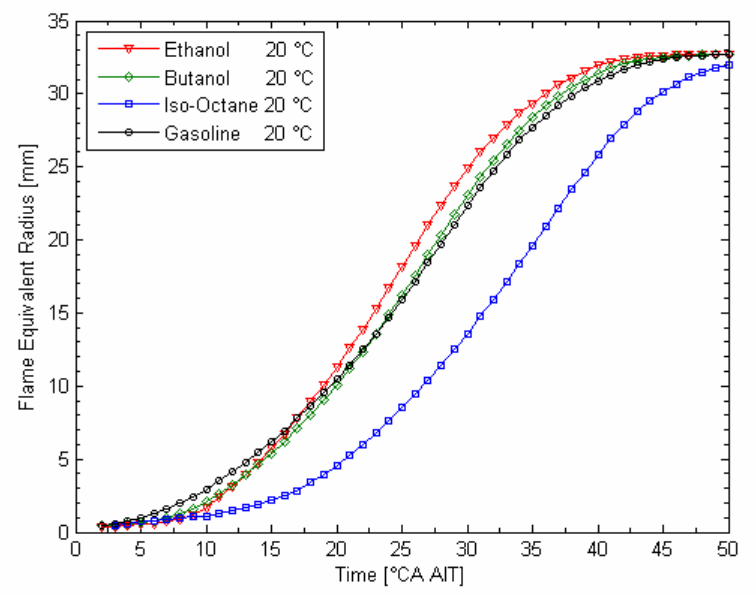

Figure 14. Flame Radius, $20^{\circ} \mathrm{C}$.

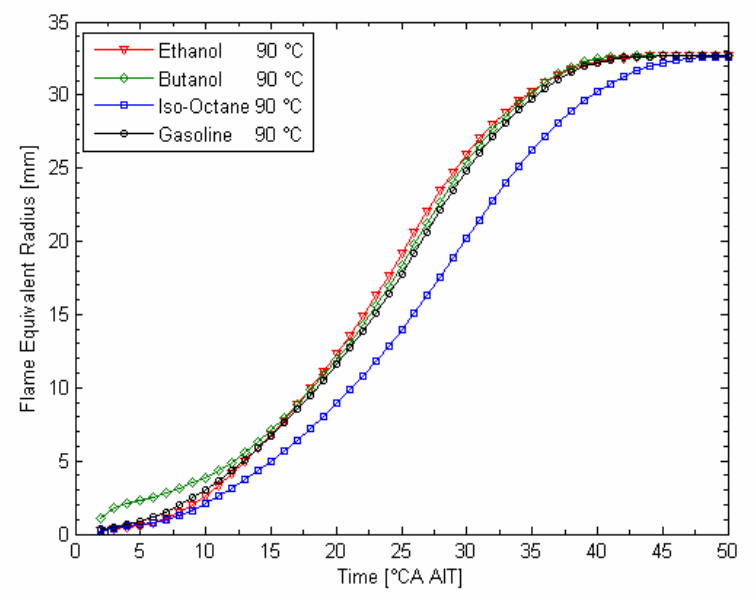

Figure 15. Flame Radius, $90^{\circ} \mathrm{C}$.

It can be seen in Figure 14 that at $20^{\circ} \mathrm{C}$ gasoline exhibits a noticeably faster initial flame growth in the period $0-15^{\circ}$ CA AIT compared to the other fuels and that over the same period of growth ethanol and butanol flames behave quite similarly. However, butanol is seen to have a marginally higher flame radius at $\sim 10^{\circ} \mathrm{CA}$ AIT. Analysis of the individual flame images showed that both gasoline and butanol exhibited particularly luminous initial flame kernels during the spark discharge which contributed to the higher flame areas calculated at this early stage. The flame growth period $15-30^{\circ}$ CA AIT (roughly corresponding to the duration of the $5-10 \%$ MFB period) shows ethanol growing faster than gasoline and butanol. Butanol is marginally faster than gasoline, with iso-octane being the slowest of the four fuels. These trends are consistent with the MFB curves shown earlier in Figures 10 and 12 and seem to be in accordance with laminar burning velocity correlations for ethanol and isooctane, e.g. $[9,10]$.

At $90{ }^{\circ} \mathrm{C}$ engine coolant temperature, the trends in Figure 15 are similar to those at $20{ }^{\circ} \mathrm{C}$, but previous differences in flame sizes and flame growth rates are smaller. Initially, gasoline flames are still marginally larger than those of ethanol and the initial kernel growth for iso-octane is significantly faster than at $20^{\circ} \mathrm{C}$. For butanol, large initial flame radii are again calculated; indeed when the flames for this fuel were revisited it was observed that there were consistently high luminosity sparks with bright flame kernels growing directly from those sparks without a drop in luminosity. This results in artificially larger initial flame radii. The later period of flame growth from $\sim 12^{\circ} \mathrm{CA}$ AIT onwards is seen to realign itself to the trends seen for $20^{\circ} \mathrm{C}$ in Figure 14 .

Flame Centroid Motion: Early kernel growth is generally believed to be affected by two main features of the flowfield: large-scale convection by 'bulk' motion and smallscale turbulence. The flame centroid displacement can be seen as an indication of the movement of the flame kernel due to flows around it during its growth. Figures 16 and 17 show the calculated flame centroid coordinates from $3-60^{\circ}$ CA AIT for all fuels at engine coolant temperatures of $20{ }^{\circ} \mathrm{C}$ and $90{ }^{\circ} \mathrm{C}$, respectively. The $(0,0)$ point represents the spark-plug electrode point just below the platinum tip as superimposed on the graph. The end centroid points are the same for all fuels as the flame fills the whole window and this point is directly equivalent to the centre of the piston crown.

The flame centroid displacement showed similar trends in Figures 16 and 17 for all fuels in that all flames grew initially towards the exhaust side before expanding into the intake side, as has also been observed previously in this engine with the same injection strategy [11]. In Figure 16 for the engine coolant at $20{ }^{\circ} \mathrm{C}$, ethanol appears to have a longer flame centroid path than gasoline and butanol, although iso-octane showed similar flame centroid displacement pattern to ethanol albeit skewed towards the right side of the combustion chamber. At this cold operating condition it appears that groups of fuels with similar boiling points have flame centroid displacements in similar directions i.e. isooctane and butanol, ethanol and gasoline. The effect does not appear to be replicated at $90^{\circ} \mathrm{C}$ engine coolant temperature in Figure 17 however, which suggests that there may be different mechanisms responsible for this behaviour at temperatures approaching the boiling points of the fuels. It could be hypothesized that at low temperatures the flame displacement from the spark plug is more dependent on the local concentration field of air/fuel ratio, which would point to fuels with similar evaporation histories following similar flame centroid motion paths. On the other hand, at high temperatures, 
the increased levels of evaporation and therefore mixture homogeneity (with early injection) may bias the sensitivity of flame motion toward dependency on the local velocity flow field, over the concentration field. This would explain to some extent the greater similarity of the flame motion for all fuels at high temperatures; it has been shown by Particle Image Velocimetry (PIV) studies $[30,31]$ that the mean flow-field for this engine on the swirl plane is nearly symmetrical between the left and right side of the combustion chamber, with a central channel running through the centre of the combustion chamber from intake to exhaust side. However, the striking similarity in Figure 17 between the behaviour of the two alcohols versus the behaviour of iso-octane and gasoline, is worth pointing out and requires further investigation.

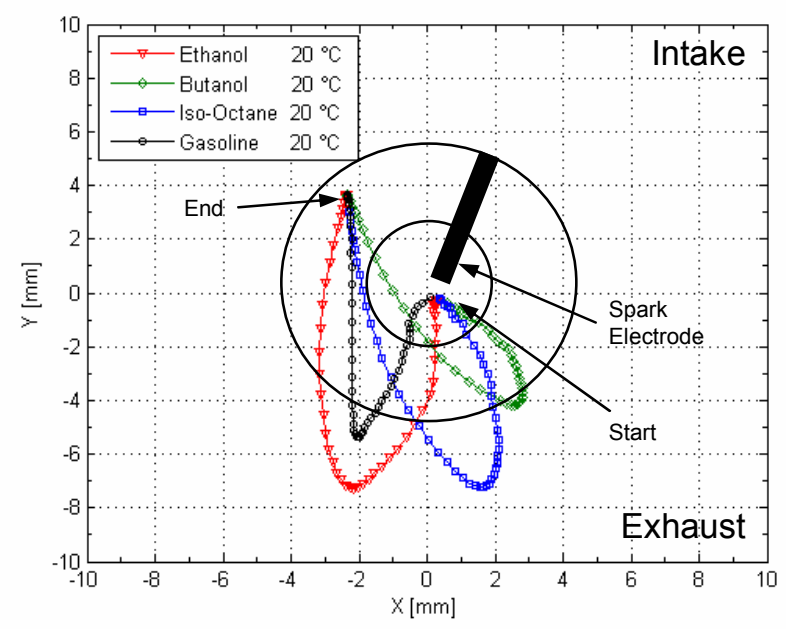

Figure 16. Flame Centroids, $20^{\circ} \mathrm{C}$.

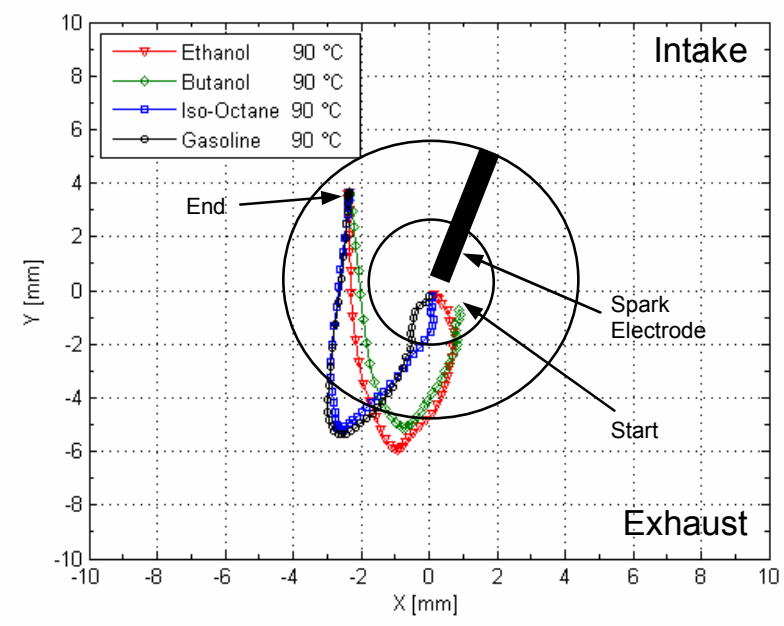

Figure 17. Flame Centroids, $90^{\circ} \mathrm{C}$.

\section{CONCLUSIONS}

Time-resolved images of fuel spray development and flame growth were acquired in an optical DISI engine. The injector used was centrally-mounted with a multihole arrangement and the measurements were conducted for stoichiometric conditions with start of injection $80^{\circ} \mathrm{CA}$ after intake TDC and a spark advance of $35^{\circ} \mathrm{CA}$ before compression TDC. The engine was operated at 1500 RPM with 0.5 intake pressure and the behavior of single and multi-component fuels, namely ethanol, butanol, iso-octane and gasoline was captured with engine-coolant temperatures of $20^{\circ} \mathrm{C}$ and $90^{\circ} \mathrm{C}$.

The engine coolant temperature was seen to have a more pronounced effect on spray formation with fuels having boiling points below or close to the coolant temperature, namely ethanol and gasoline which is made up of a large percentage of high volatility (low boiling point) components. In the extreme, at $90{ }^{\circ} \mathrm{C}$ enginecoolant temperature, the ethanol and gasoline sprays were seen to partially collapse and produce a spray 'cloud' with a footprint directly below the injector nozzle, with gasoline collapsing more fiercely than ethanol. Isooctane sprays never collapsed and retained good directionality even at $90{ }^{\circ} \mathrm{C}$, showing only increased levels of spray tip vaporization; butanol behaved similarly at both $20^{\circ} \mathrm{C}$ and $90{ }^{\circ} \mathrm{C}$ with small changes in spray plume geometries apart from wider plumes and the increased effect of air entrainment into the spray plumes at $90{ }^{\circ} \mathrm{C}$. An improvement in evaporation rates resulted in slightly faster plume break-up in a similar but less pronounced fashion to that seen with iso-octane.

Projected spray and flame areas were calculated from the images acquired through the piston crown (for the purposes of analysis the spray areas were compared using the same fuel pulse-widths for all fuels) and specific conclusions may be summarised as follows:

- The spray development for gasoline and iso-octane was very similar at $20^{\circ} \mathrm{C}$ engine coolant temperature and this is reflected in the calculated spray areas which show similar growth rates and peaks at end of injection. After the end of injection, the spray areas for iso-octane reduced markedly faster than for gasoline, resulting in a $60 \%$ reduction in spray areas with respect to their peak values compared to only $20 \%$ for gasoline at $25^{\circ} \mathrm{CA}$ ASOI.

- For the alcohol fuels, the growth rates of spray areas were lower than for both iso-octane and gasoline, showing peak values of spray area at end of injection $10 \%$ lower for ethanol and $20 \%$ lower for butanol relative to the two former fuels. The post injection period for the two alcohols at $20{ }^{\circ} \mathrm{C}$ showed similar behaviour to the gasoline fuel with marginally smaller spray areas but higher than those seen for isooctane.

- At $90{ }^{\circ} \mathrm{C}$ engine coolant temperature the start of injection period was very similar for most of the tested fuels in terms of spray areas, apart from butanol which showed slower initial growth rates and gasoline which collapsed immediately as it exited the injector nozzles. The peak values of spray area were highest for ethanol, with gasoline, butanol and isooctane following. Partial spray collapse for ethanol 
increased the spray areas by $20 \%$ over those at $20{ }^{\circ} \mathrm{C}$ due to a wider scattering area. The spray area $25^{\circ}$ CA ASOI was also $\sim 8 \%$ lower due to increased evaporation at the spray-gas interfaces.

- Gasoline sprays collapsed more than ethanol sprays at $90{ }^{\circ} \mathrm{C}$ engine coolant temperature but resulted in peak spray areas which were lower than those measured at $20{ }^{\circ} \mathrm{C}$ by $\sim 6 \%$. This occurred due to the reduction in outward radial momentum by the spray collapse which in turn reduced the projected spray footprint as observed through the piston crown. The spray area $25^{\circ} \mathrm{CA}$ ASOI was reduced at $90{ }^{\circ} \mathrm{C}$ by nearly $50 \%$ relative to that at $20{ }^{\circ} \mathrm{C}$, highlighting the faster evaporation rates of the low boiling point fractions in the gasoline fuel at fully warm conditions.

- The peak spray areas for butanol at $90{ }^{\circ} \mathrm{C}$ were higher than at $20{ }^{\circ} \mathrm{C}$ by $\sim 10 \%$ due to swelling of the spray plumes and were similar to those calculated for gasoline. The period after the end of injection however, showed a slower rate of decline in terms of spray areas, highlighting the 'heavy' nature of this fuel, with the single highest boiling point of $\sim 118{ }^{\circ} \mathrm{C}$ (i.e. significantly above the engine coolant temperature), and the spray areas $25^{\circ} \mathrm{CA}$ ASOI were thus similar to those calculated at $20^{\circ} \mathrm{C}$.

- Iso-octane was the only fuel that showed a large change in behaviour post injection at $90{ }^{\circ} \mathrm{C}$. The peak value of spray area was reduced by $25 \%$ from the peak value at $20^{\circ} \mathrm{C}$ and this effect continued even after the end of injection with rapidly decreasing spray areas which were nearly zero by $25^{\circ} \mathrm{CA}$ ASOI.

- Flame growth at $20^{\circ} \mathrm{C}$ engine coolant temperature was initially faster for gasoline up to $\sim 15^{\circ} \mathrm{CA}$ AIT, at which point ethanol flame development became noticeably faster, as expected from laminar burning velocity correlations. Iso-octane was the slowest in the group by some margin at both $20^{\circ} \mathrm{C}$ and $90^{\circ} \mathrm{C}$.

- Butanol flame development was very similar to that of gasoline at both $20{ }^{\circ} \mathrm{C}$ and $90{ }^{\circ} \mathrm{C}$ engine coolant temperatures, with a marginally faster main period of flame development relative to gasoline. At $90{ }^{\circ} \mathrm{C}$ however, in the first $15^{\circ} \mathrm{CA}$ AIT, butanol showed a particularly large equivalent flame radius due to the high luminosity of the spark and initial flame kernel.

- All fuels showed a tendency for flame growth towards the exhaust valves, although the $90{ }^{\circ} \mathrm{C}$ engine coolant temperature tests showed smaller variations in the flame centroid paths for all fuels than the $20{ }^{\circ} \mathrm{C}$ engine coolant temperature tests. Interestingly, at $90{ }^{\circ} \mathrm{C}$ both alcohols followed very similar flame centroid paths to one another, whilst iso-octane and gasoline also exhibited similar behaviour to one another. This may indicate subtle similarities in the mixture preparation process for these two groups of fuels but further investigation is necessary to substantiate this hypothesis.

\section{ACKNOWLEDGMENTS}

The authors would like to thank Jaguar Advanced Powertrain Engineering for technical and financial support and Shell Global Solutions (UK) for fuel supplies.

\section{REFERENCES}

1. defra.gov.uk, "Key Facts about: Climate Change, Carbon Dioxide Emissions by End User: 19702005", 2007.

2. Kleeberg, H. and Monnier, G., "Downsizing a Gasoline Engine Using Turbocharging with Direct Injection", SAE Paper 2003-01-0542, 2003.

3. Bandel, W., Fraidl, G.K., Kapus, P.E., Sikinger, H. and Cowland, C.N., "The Turbocharged GDI Engine: Boosted Synergies for High Fuel Economy Plus Ultra-Low Emissions", SAE Paper 2006-01-1266, 2006.

4. Kapus, P.E., Fuerhapter, Fuchs, H. and Fraidl, G.K., "Ethanol Direct Injection on Turbocharged SI Engines - Potentials and Challenges", SAE Paper 2007-01-1408, 2007.

5. Brewster, S., "Initial Development of a TurboCharged Direct Injection E100 Combustion System", SAE Paper 2007-01-3625, 2007.

6. Nakata, K., Utsumi, S., Ota, A., Kawatake, K., Kawai, T. and Tsunooka, T., "The Effect of Ethanol on a Spark Ignition Engine", SAE Paper 2006-01-3380, 2006.

7. Farell, J.T., Weissman, W., Johnston, R.J., Nishimura, J., Ueda, T. and Iwashita, Y., "Fuel Effects on SIDI Efficiency and Emissions", SAE Paper 2003-01-3186, 2003.

8. Takashi, H. and Kimitoshi, T., "Laminar Flame Speeds of Ethanol, n-heptane, Iso-Octane Air Mixtures", FISITA 2006, Yokohama, Japan, Paper SC40.

9. Gülder, Ö.L., "Burning Velocities of Ethanol-IsoOctane Blends", Combustion and Flame, Vol. 56, pp. 261-168, 1984.

10. Gülder, Ö.L., "Correlations of Laminar Combustion Data for Alternative SI Engine Fuels", SAE Paper 841000, 1984.

11. Serras-Pereira, J., Aleiferis, P.G., Richardson, D. and Wallace, S., "Mixture Preparation and Combustion Variability in a Spray-Guided DISI Engine", SAE Paper 2007-01-4033, 2007.

12. Serras-Pereira, J., Aleiferis, P.G., Richardson, D. and Wallace, S., "Spray Development, Flow Interactions and Wall Impingement in a DirectInjection Spark-Ignition Engine", SAE Paper 200701-2712, 2007.

13. Schwarzenbch, R.E., Gschwend, P.M., and Imboden, D.M., "Environmental Organic Chemistry", John Wiley and Sons, 1993. 
14. Kaye, G.W.C. and Laby, T.H., "Tables of Physical and Chemical Constants", $16^{\text {th }}$ Ed., Longman, 1995.

15. Adamson, A.W. and Gast, A.P., "Physical Chemistry of Surfaces", $6^{\text {th }}$ Ed., John Wiley and Sons, 1997.

16. Lide, D.R., "CRC Handbook of Chemistry and Physics", 74 ${ }^{\text {th }}$ Ed., CRC Press, 1994.

17. Aleiferis, P.G. and van Romunde, Z., "Effect of Operating Conditions and Fuel Volatility on Development and Variability of Sprays from Gasoline Direct Injection Multi-Hole Injectors", Atomization and Sprays, in Press, 2007.

18. van Romunde, Z., Aleiferis, P.G., Cracknell, R.F. and Walmsley, H.L., "Effect of Fuel Properties on Spray Development from a Multi-Hole DISI Engine Injector", SAE Paper 2007-01-4032, 2007.

19. Skogsberg, M., Dahlander, $P$, Lindegren, R. and Denbratt, I., "Effects of Injector Parameters on Mixture Formation for Multi-Hole Nozzles in a SprayGuided Gasoline DI Engine", SAE Paper 2005-010097, 2005.

20. Nauwerck, A., Pfeil, J., Velji, A., Spicher, U. and Richter, B., "A Basic Experimental Study of Gasoline Direct Injection at Significantly High Injection Pressures", SAE Paper 2005-01-0098, 2005.

21. Beyrau, F., Weikl, M.C., Schmitz, I., Seeger, T. and Leipertz, A., "Locally Resolved Investigation of the Vaporization of GDI Sprays Applying Different Laser Techniques", Atomization and Sprays, Vol. 16, pp. 319-330, 2006.

22. Aleiferis, P.G., Serras-Pereira, J., van Romunde, Z., Richardson, D., Wallace, S., Cracknell, R.F. and Walmsley, H.L., "Optical Studies of Spray Development in a Quiescent Chamber and in a Direct-Injection Spark-Ignition Engine", International Conference on Internal Combustion Engines: Performance, Fuel Economy and Emissions, pp. 313, Paper C660/024/07, IMechE, London, December 11-12, 2007.

23. Aleiferis, P.G., Malcolm, J.S., Todd, A.R., Cairns, A. and Hoffmann, H., "An Optical Study of Spray Development and Combustion of Ethanol, IsoOctane and Gasoline Blends in a DISI Engine", SAE Paper 2008-01-0073, 2008.

24. Lefebvre, A.H., "Atomization and Sprays", Taylor and Francis, 1989.

25. Gilles-Birth, I., Rechs, M., Spicher, U. and Bernhardt, S., "Experimental Investigation of the In-Nozzle Flow of Valve Covered Orifice Nozzles for Gasoline Direct Injection", Proceeding of the $7^{\text {th }}$ International Symposium on Internal Combustion Diagnostics, pp. 59-78, AVL, Baden-Baden, Germany, May 18-19, 2006.

26. Papoulias, D., Giannadakis, E., Mitroglou, N., Gavaises, M. and Theodorakakos, A., "Cavitation in Fuel Injection Systems for Spray-Guided Direct Injection Gasoline Systems", SAE Paper 2007-011418, 2007.

27. Aleiferis, P.G., Hardalupas, Y., Kolokotronis, D., Taylor, A.M.K.P., Arioka, A. and Saito, M.,
"Experimental Investigation of the Internal Flow Field of a Model Gasoline Injector Using Micro-Particle Image Velocimetry", SAE Paper 2006-01-3374, 2006.

28. Naber, J. and Reitz, R., "Modeling Engine Spray/Wall Impingement", SAE Paper 880107, 1988.

29. Shih, L. and Assanis, D., "Implementation of a Fuel Spray Wall Interaction Model in KIVA -II", SAE Paper 911787, 1991.

30. Jarvis, S., Justham, T., Clarke, A., Garner, C.P., Hargrave, G.K. and Richardson, D., "Motored SI IC Engine In-Cylinder Flow Field Measurement Using time Resolved Digital PIV for Characterisation of Cyclic Variation", SAE Paper 2006-01-1044, 2006.

31. Justham, T., "Cyclic Variability of Engine Intake and In-Cylinder Flows" PhD Thesis, Loughborough University, Wolfson School of Mechanical and Manufacturing Engineering, UK, in Preparation, 2007.

\section{ABBREVIATIONS}

$\begin{array}{ll}\text { AFR } & \text { Air to Fuel Ratio } \\ \text { AIT } & \text { After Ignition Timing } \\ \text { ASOI } & \text { After Start Of Injection } \\ \text { ATDC } & \text { After intake Top Dead Centre } \\ \text { CA } & \text { Crank Angle } \\ \text { COV } & \text { Coefficient Of Variation } \\ \text { DISI } & \text { Direct Injection Spark Ignition } \\ \text { ETU } & \text { Engine Timing Unit } \\ \text { EVC } & \text { Exhaust Valve Closure } \\ \text { EVO } & \text { Exhaust Valve Open } \\ \text { IMEP } & \text { Indicated Mean Effective Pressure } \\ \text { IVC } & \text { Intake Valve Closure } \\ \text { IVO } & \text { Intake Valve Open } \\ \text { MBT } & \text { Minimum spark advance for Best Torque } \\ \text { MFB } & \text { Mass Fraction Burnt } \\ \text { PIV } & \text { Particle Image Velocimetry } \\ \text { RON } & \text { Research Octane Number } \\ \text { RPM } & \text { Revolutions Per Minute } \\ \text { SOI } & \text { Start Of Injection } \\ \text { TDC } & \text { Top Dead Centre }\end{array}$

\section{SYMBOLS}

$\mathrm{P}_{\max } \quad$ Maximum in-cylinder pressure

$\theta_{\mathrm{Xb} 50 \%} \quad$ Crank angle of $50 \% \mathrm{MFB}$

$\Phi \quad$ Equivalence ratio

\section{CONTACT}

Author for correspondence:

Dr. Pavlos Aleiferis

Department of Mechanical Engineering

University College London

Torrington Place

London WC1E 7JE

United Kingdom

E-mail: p_aleiferis@meng.ucl.ac.uk 